\title{
Posterior Lumbar Stabilization Surgery under Spinal Anesthesia for High-Risk Patients with Degenerative Spondylolisthesis, Spinal Stenosis and Lumbar Compression Fracture
}

\author{
Dejeneratif Spondilolistezis, Spinal Stenoz, Lomber Kompresyon \\ Fraktürü Olan Yüksek Riskli Hastalarda Spinal Anestezi ile Posterior \\ Lomber Stabilizasyon Cerrahisi
}

Yahya Cem ERBAS ${ }^{1}$, Serhat PUSAT $^{2}$, Erdal YILMAZ ${ }^{3}, Z_{\text {uleyha KAZAK BENGISUN }}^{4}$, Ersin ERDOGAN ${ }^{5}$

${ }^{1}$ Bilgi Hospital, Department of Neurosurgery, Ankara, Turkey

${ }^{2}$ Etimesgut Military Hospital, Department of Neurosurgery, Ankara, Turkey

${ }^{3}$ Diskapi Education and Training Hospital, Department of Neurosurgery, Ankara, Turkey

${ }^{4}$ Ufuk University, School of Medicine, Department of Anesthesia, Ankara, Turkey

${ }^{5}$ Ufuk University, School of Medicine, Department of Neurosurgery, Ankara, Turkey

Corresponding Author: Serhat PUSAT / E-mail: pusatserhat@yahoo.com

\begin{abstract}
AIM: Spinal anesthesia is an appropriate technique for lumbar spine surgeries of two to three hours duration. The aim of this study is to document our experience on spinal anesthesia administered to the patients with degenerative lumbar spine.

MATERIAL and METHODS: A total of 497 patients underwent spinal stabilization surgery with spinal anesthesia for degenerative lumbar spinal disorders in an 8-year period. Spinal anesthesia was performed at the L3-L4 or L4-L5 level and subarachnoid block was achieved with $15 \mathrm{mg}$ of $0.5 \%$ plain bupivacaine with $2 \mu \mathrm{g}$ of fentanyl and $0.2 \mathrm{mg}$ of epinephrine. There was no failure of anesthesia. The patients were closely monitored for complications associated with the SA technique and especially hypotension and bradycardia but no gross alterations in cardiovascular stability were noted.

RESULTS: Among the 497 patients, 139 were male and 358 were female with a median age of 51 years. The average anesthesia duration was 130 minutes and the average operative time was 85 minutes. In the postoperative period 36 patients has nausea (7.2\%) and 18 of them had vomiting (3.6\%) that required one dose of antiemetic. No spinal headache was observed and $36(7.2 \%)$ patients complained of urinary retention. All recovered with urinary cannulation within 24 hours. No respiratory complication occurred and no patient died.
\end{abstract}

CONCLUSION: Spinal anesthesia is a safe and effective procedure for the lumbar spinal stabilization surgery, especially in high-riskpatients. Proper precautions should be taken in order to achieve an effective anesthesia for these operations.

KEYWORDS: Spinal anesthesia, Spinal stabilization, Surgery

öz

AMAÇ: Spinal anestezi 2 ile 3 saat arasındaki lomber spinal cerrahiler için uygun tekniktir. Çalışmanın amacı dejeneratif lomber omurgası olan hastalarda uygulanan spinal anestezi ile ilgili tecrübemizi sunmaktır.

YÖNTEM ve GEREÇLER: Sekiz yıllık süre içerisinde dejeneratif lomber spinal hastalığı olan toplam 497 hastaya spinal anestezi ile spinal stabilizasyon cerrahisi uygulandı. Spinal anestezi L3-L4 veya L4-L5 seviyelerinden uygulandı ve subaraknoid blok \% 0,5'lik 15 mg bupivakain ve $2 \mu \mathrm{g}$ fentanil ve 0,2 mg epinefrin karışımı ile sağlandı. Başarısı anestezi olmadı. Hastalar spinal anestezinin komplikasyonları (özellikle hipotansiyon ve bradikardi) yönünden yakından takip edildi. Ancak hiçbir hastada kardiyovasküler stabilitede önemli bir bozulma gözlenmedi. BULGULAR: Toplam 497 hastanın 139 tanesi erkek, 358 tanesi ise bayandı ve ortalama yaş 51 idi. Ortalama anestezi süresi 130 dakika ve ortalama ameliyat süresi ise 85 dakika olarak hesaplandı. Postoperatif dönemde $36(\% 7,2)$ hastada bulantı oldu ve bunların $18(\% 3,6)$ tanesinde kusma görüldü. Bir doz antiemetik ile düzeldi. Spinal anesteziye bağlı başağrısı hiçbir hastada görülmedi ancak 36 (\%7,2) hastada üriner retansiyon görüldü ve bu da 24 saat içinde üriner kanülasyon ile düzeldi. Solunum sıkıntısı görülmedi ve hiçbir hasta ölmedi.

SONUÇ: Spinal anestezi özellikle yüksek riskli hasta grubunda lomber stabilizasyon cerrahisi için güvenli ve etkili bir yöntemdir. Bu tür ameliyatlarda etkin anestezinin sağlanması için uygun tedbirlerin alınması gereklidir.

ANAHTAR SÖZCÜKLER: Spinal anestezi, Spinal stabilizasyon, Cerrahi 


\section{INTRODUCTION}

General anesthesia (GA) and spinal anesthesia (SA) have both been shown to be suitable techniques for patients undergoing lumbar spine surgery $(3,6,8)$ but GA is routinely used in most spinal practices (1).

Anesthesiologists often favour SA because it reduces blood loss, ensures hemodynamic instability, and improves operating conditions by decreasing peripheral venous pressure that also reduces venous blood loss in the operative field $(1,4,5,9)$. In addition, in the prone position, the awake patient can self-position to avoid brachial plexus injury and pressure necrosis to the face that may occur in the malpositioned patient under GA. Pulmonary complications are reported to occur less frequently with SA compared with $\mathrm{GA}(11,13,15)$.

SA is widely used technique for lumbar spine surgery especially for laminectomies $(6,9,16,18)$ but its use for posterior lumbar stabilization surgery has not been reported yet. However, a significant number of patients who present a high surgical risk have undergone posterior lumbar stabilization surgery with GA $(12,14)$. SA is not routinely used for posterior lumbar stabilization surgery, even for high-risk patients, despite the fact that degenerative spondylolisthesis, spinal stenosis and lumbar compression fractures often implies the patient population is elderly with pre-existing comorbidities $(7,8,10$, 17, 18).

The aim of this study was to determine the outcomes of SA in patients with degenerative spondylolisthesis, spinal stenosis and lumbar compression fractures who underwent posterior lumbar stabilization surgery.

\section{MATERIAL and METHODS}

A retrospective study was undertaken to review the use of $\mathrm{SA}$ in patients undergoing posterior lumbar stabilization surgery. 497 surgeries were performed on patients with degenerative spondylolisthesis, spinal stenosis and vertebra fracture between March 2007 and March 2015. The gender and age distribution of the patients are presented in Tables I, II. All surgical procedures were performed by the same neurosurgeon and the anesthesia was ensured by the same anesthetist. The additional diseases that may pose a surgical problem for the patients are presented in Table III. All patients were classified by the anesthetist as American Society of Anesthesiology (ASA) grades 1, 2, 3 or 4. The medical conditions causing the patients to be considered as high-risk are shown in Table IV. All patients underwent radiological examinations with computed tomography and magnetic resonance imaging. Based on these examinations, the preoperative diagnoses of the patients were lumbar spondylolisthesis, recurrent lumbar disc herniation, lumbar spinal stenosis, and lumbar compression fracture (Table V). We treated all of these 497 patients with posterior lumbar stabilization and laminectomy, discectomy, and if necessary posterior lumbar interbody fusion. All the patients received intravenous antibiotic before surgery and orally thereafter until 2 days after discharge from the hospital.
Table I: Distribution of the Patients According to Gender

\begin{tabular}{|l|c|}
\hline Gender & Number of patients \\
\hline Female & 358 \\
\hline Male & 139 \\
\hline Total & 497 \\
\hline
\end{tabular}

Table II: Distribution of the Patients According to Age

\begin{tabular}{|l|c|}
\hline Age interval & Number of patients \\
\hline Less than 30 years & 4 \\
\hline $31-40$ years & 20 \\
\hline $41-50$ years & 54 \\
\hline $51-60$ years & 134 \\
\hline $61-70$ years & 166 \\
\hline $71-80$ years & 92 \\
\hline More than 80 years & 27 \\
\hline
\end{tabular}

Table III: Additional Diseases in Patients Who Underwent Stabilization Surgery with Spinal Anesthesia

\begin{tabular}{|l|c|}
\hline Disease & Number of patients \\
\hline Diabetes & 185 \\
\hline Cardiac disease & 160 \\
\hline Hypertension & 172 \\
Chronic obstructive pulmonary & 84 \\
disease & 3 \\
\hline Allergy & 37 \\
\hline Goiter & \\
\hline
\end{tabular}

Table IV: Distribution of the Patients According to the Preoperative Anesthesia Risk (Based on ASA Classification)

\begin{tabular}{|l|r|}
\hline ASA & Number of patients \\
\hline ASA 1 & 57 \\
\hline ASA 2 & 124 \\
\hline ASA 3 & 251 \\
\hline ASA 4 & 65 \\
\hline Total & 497 \\
\hline
\end{tabular}

Table V:Distribution of the Patients According to the Preoperative Diagnosis

\begin{tabular}{|l|c|}
\hline Diagnosis & Number of patients \\
\hline Vertebrae fracture & 23 \\
\hline Recurrent lumbar disc herniation & 24 \\
\hline Lumbar spondylolisthesis & 157 \\
\hline Lumbar spinal stenosis & 293 \\
\hline Total & 497 \\
\hline
\end{tabular}


Table VI: Complications of the Stabilization Operations

\begin{tabular}{|l|c|}
\hline Complications & Number of patients \\
\hline Bleeding & 2 \\
\hline Neurological deficit & 0 \\
\hline Infection & 0 \\
\hline CSF fistula & 2 \\
\hline Pulmonary problems & 0 \\
\hline Cardiac problems & 0 \\
\hline Allergy & 5 \\
\hline Death & 0 \\
\hline Total & 9 \\
\hline
\end{tabular}

SA was suggested to the patients as an option or alternative to the GA. The risk and benefits of both techniques were discussed with the patients and their relatives and the final decision was made by the patients. All patients were informed about the risks and benefits of spinal anesthesia before the surgery. After obtaining informed consent, a spinal anesthetic was administered for all 497 patients. Prehydration was performed in the operation room with 300 to $500 \mathrm{ml}$ of lactated Ringer solution intravenously. The spinal anesthetic was administered to the patient in the sitting position. After sterile preparation, the best interspace at the L3-4 or L4-5 level was identified and a local anesthetic was administered into the skin and superficial tissues using a 25-gauge needle. Dural puncture was performed using a 22-gauge Quince needle and subarachnoid block was achieved with $15 \mathrm{mg}$ of $0.5 \%$ plain bupivacaine with $2 \mu \mathrm{g}$ of fentanyl and $0.2 \mathrm{mg}$ of epinephrine. The patient was returned to the supine position, and as soon as there was clear evidence of subarachnoid block at T-12 or above, the patient was turned to the prone position on the operating bed. A pillow was applied to allow easy breathing and to relieve anxiety about the face being covered. Oxygen was administered by a nasal cannula at $2 \mathrm{~L} /$ minute. No supplemental sedation was given to avoid increased risk of hypotension and cardiovascular instability. At the end of the procedure, the patient was transferred to the Post-anesthesia Recovery Unit (PARU).

There was no failure of anesthesia. Surgery was successfully completed in all patients. The patients were closely monitored for complications associated with the SA technique and especially hypotension and bradycardia but no gross alterations in cardiovascular stability were noted.

Age, sex, height, weight and ASA score were recorded at the time the patient first entered the operation room. Total anesthesia duration (time from the patient's entry into the operating room until transfer to the PARU) and operative time (time from incision to placement of the surgical dressing) were documented.

Patients' complaints of pain or nausea, or episodes of vomiting during the postoperative period were recorded in the nursing notes. Pain was treated with self-controlled intravenous morphine. Postoperative complications such as headache, urinary retention or pulmonary dysfunction were recorded. The patients who underwent surgery on more than 2 levels required a blood transfusion. Postoperative surgical complications were also recorded.

\section{RESULTS}

The study cohort consisted of 139 men and 358 (72\%) women, and the median age was 51 (range 29-84) years (Table I, II). Of the 497 patients, 57 patients were ASA-1, 124 patients were ASA-2, 251 (50.5\%) were ASA-3 and 65 were ASA-4. Most $(63.5 \%)$ of the patients were ASA-3 in the preoperative period.

The mean duration of anesthesia was 130 minutes (range 50-180 minutes) but the duration was shortened in case of dural injury and cerebrospinal fluid (CSF) loss, The average operative time was 85 minutes (range 45-145 minutes) and the average blood loss was $400 \mathrm{ml}$ (range 200-1300 ml).

No patient died in this series. All patients were mobilized 8 hours after surgery. The average duration of hospital stay was 2 days.

In the postoperative period 36 patients has nausea (7.2\%) and 18 experienced vomiting (3.6\%) that required 1 dose of antiemetic. The postoperative narcotic requirement was 0.5 mg morphine sulphate/hour. No headache was observed and 36 (7.2\%) patients complained of urinary retention. All recovered within 24 hours with urethral cannulation. No respiratory complication occurred. A CSF fistula was the most common surgical complication and was observed in 5 (1\%) patients. The postoperative complications secondary to spinal stabilization surgery are summarized in Table VI.

\section{DISCUSSION}

This study supports the role of SA technique for the management of patients undergoing posterior lumbar spinal stabilization surgery. Posterior lumbar stabilization can be performed under SA without mortality and with very low morbidity. In this study, $63.5 \%$ of the patients were ASA 3 and 4, considered as high-risk patients. It is notable that there was no respiratory complication, which is one of the most common causes of morbidity and mortality in high-risk surgical patients. SA has been associated with complications such as hypotension, and bradycardia in previous studies (3, $10,11)$. However in our study, no morbidity attributable to the anesthetic technique occurred.

Neurosurgeons and spine surgeons are now increasingly confronted with degenerative changes of the lumbar spine because of the aging population $(10,19)$. Degenerative changes of the lumbar spine that are diagnosed by computed tomography and magnetic resonance imaging become more common with age and are present in all patients over 60 years old (10). The treatment options for degenerative lumbar spine range from analgesic medication to extensive posterior stabilization surgery. The goal of surgery in these degenerative diseases is to decompress the nerve roots, dura mater, and vessels without impairing the spinal stability. 
Therefore, it must first be determined whether the patient has spinal stenosis, spondylolisthesis or fracture alone or associated with spinal instability. Presence of lumbar spinal instability is a universally accepted indication for stabilization surgery $(3,4)$. We believe that the appropriate posterior stabilization system should be used for the management of degenerative spondylolisthesis, spinal stenosis, and lumbar compression fracture in elderly, high-risk patients with history of neurogenic claudication or vesicorectal symptoms. Based on scientific knowledge, conservative treatment options are worthless most of the time in this patient group and the patients should preferably have surgical treatment $(10,19)$.

GA is the preferred technique for spinal stabilization surgery $(1,5)$. However, high-risk patients may not tolerate the complications or side effects of GA (11). Patients with highrisk medical conditions such as poorly controlled diabetes, cardiac or coronary disease, uncontrolled hypertension, chronic obstructive pulmonary disease, allergy and goiter were considered high-risk patients. However, GA is not without risk. The possible complications of GA in high-risk patients are headache, backache, nausea and vomiting, damage to the teeth, sore throat and laryngeal injury or spasm, anaphylaxis secondary to anesthetic agents, cardiovascular collapse, respiratory depression, aspiration pneumonia, hypothermia, hypoxic brain damage, nerve injury due to positioning, embolism (air or thrombus), and death. SA is therefore more suitable for high-risk patients.

Knowing the level of surgical anesthesia is extremely important since this will determine whether the patient can comfortably undergo the procedure and avoid the hemodynamic consequences of surgical stimulation (7). Therefore, SA is an alternative for the high-risk group of patients. Anesthesia levels adequate for lumbar surgery can be easily achieved with hyperbaric or isobaric local anesthetics. Typically, a dermatomal sensory level of at least T6-T8 will be required for L1-L5 surgery. Though this is higher than the level of the operative site, the higher level will allow for the surgery to take place and, depending on the local anesthetic selected, allow for a slow regression of surgical anesthesia coverage $(13,14)$. The patient is placed in the full prone position in most instances but we preferred spinal anesthesia in the sitting position and then the patient was positioned prone for surgery.

Bupivacaine appears to be the agent of choice since it provides adequate duration of coverage $(2,4,7)$. In addition, some physicians select additives to the local anesthetic such as opioids, epinephrine, phenylephrine, neostigmine and clonidine. In our series, we used $15 \mathrm{mg}$ of $0.5 \%$ plain bupivacaine with $2 \mu \mathrm{g}$ of fentanyl and $0.2 \mathrm{mg}$ of epinephrine for spinal anesthesia. This provided comfort for the patients during the spinal surgery.

Sedation is used in regional anesthesia to reduce anxiety and improve patient comfort and cooperation (12). Although spinal anesthesia provides anesthesia of the surgical site, unpleasant and uncomfortable patient experiences result from having to remain in the same position, prolonged duration of surgery, or the ambient noise in the operating room $(7,9,15)$. It should be kept in mind that the agents for sedation may cause airway obstruction requiring intervention. In addition, older patients demonstrate delayed recovery of psychomotor function after sedation. In our study, no additional sedation was used for our patients in order to avoid the morbidities of the sedation such as delayed recovery, airway obstruction, hypoxia, hypotension, and excitation $(5,8)$.

This study demonstrates that the implementation of the SA technique in patients undergoing posterior lumbar stabilization can have significant advantages. SA is an effective, safe and low-risk option especially in patients in the ASA 3 or 4 risk groups undergoing posterior lumbar stabilization.

\section{CONCLUSION}

Spinal stabilization surgery presents a number of challenges to the anesthetist. High-risk patients may undergo stabilization surgery for spondylolisthesis, spinal stenosis and compression fractures. Postoperative neurological morbidity has been reduced by advances in spinal anesthesia and analgesia techniques. The anesthetist may play an important role in facilitating spinal stabilization procedures.

\section{REFERENCES}

1. Attari MA, Mirhosseini SA, Honarmand A, Safavi MR: Spinal anesthesia versus general anesthesia for elective lumbar spine surgery: A randomized clinical trial. J Res Med Sci 16:524-529, 2011

2. Brown DL: Spinal, epidural, and caudal anesthesia. In: Miller RD (ed), Miller's Anesthesia. $7^{\text {th }}$ ed. Philadelphia: Churchill Livingstone, 2010: 1611-1637

3. Dimar JR, Fisher C, Vaccaro AR, Okonkwo DO, Dvorak $M$, Fehlings $M$, Rampersaud R, Carreon LY: Predictors of complications after spinal stabilization of thoracolumbar spine injuries. J Trauma 69(6):1497-500, 2010

4. Farmery $A D$, Wilson-MacDonald J: The analgesic effect of epidural clonidine after spinal surgery: A randomized placebo-controlled trial. Anesth Analg 108:631-634, 2009

5. Fritz HG, Kuehn D, Haberland N, Kalff R: Anesthesia management for spine surgery using spinal navigation in combination with computed tomography. Reg Anesth 20(6): 533-537, 1995

6. Goddard M, Smith PD: Spinal anaesthesia for spinal surgery. Anaesth 61:723-724, 2006

7. Jellish WS, Edelstein S: Spinal anesthesia for lower level spine surgery. In: Victor M. Whizar-Lugo (ed). Topics in Spinal Anaesthesia. InTech, 2014: 19-38

8. Jellish WS, Shea JF: Spinal anesthesia for spinal surgery. Best Pract Res Clin Anaesthesiol 17(3):323-334, 2003

9. Jellish WS, Thalji W, Stevenson K, Shea J: A prospective randomized study comparing short and intermediate-term perioperative outcome variables after spinal or general anesthesia for lumbar disc or laminectomy surgery. Anesth Analg 83:559-564, 1996 
10. Kalff R, Ewald C, Waschke A, Gobisch L, Hopf C: Degenerative lumbar spinal stenosis in older people-current treatment options. Dtsch Arztebl Int 110(37): 613-624, 2013

11. Kara I, Celik JB, Bahar OC, Apilliogullari S, Karabagli H: Comparison of spinal and general anesthesia in lumbar disc surgery. J Neuro Sci (Turkish) 28:487-496, 2011

12. Mannion S: Sedation, spinal anesthesia and older patients. J Postgrad Med 53: 155, 2007

13. McLain RF, Kalfas I, Bell GR, Tetzlaff JE, Yoon HJ, Rana M: Comparison of spinal and general anesthesia in lumbar laminectomy surgery: A case controlled analysis of 400 patients. J Neurosurg Spine 2:17-22, 2005

14. Raw DA, Beattie JK, Hunter JM: Anaesthesia for spinal surgery in adults. Br J Anaesth 91(6):886-904, 2003
15. Rung GW, Williams D, Gelb DE, Grubb M: Isobaric spinal anesthesia for lumbar disk surgery. Anesth Analg 84: 11651166, 1997

16. Sadrolsadat SH, Mahdavi AR, Moharari RS, Khajavi MR, Khashayar P, Najafi A, Amirjamshidi A: A prospective randomized trial comparing the technique of spinal and general anesthesia for lumbar disk surgery: A study of 100 cases. Surg Neurol 71(1):60-65, 2009

17. Sun KO: Spinal anaesthesia following previous spinal surgery. European J Anaesth 11:321-333, 1994

18. Tetzlaff JE, Dilger JA, Kodsy M, al-Bataineh J, Yoon HJ, Bell GR: Spinal anesthesia for elective spine surgery. J Clin Anesthesia 10:666-669, 1998

19. Vo $P$, MacMillan M: The aging spine: Clinical instability. South Med J 87(5):S26-35, 1994 